Research Article

\title{
The implementation of local wisdom-based learning and HOTS-based assessment: Teacher survey in Banjarmasin
}

\author{
A. Abidinsyah a,1, Siti Ramdiah a,2,", M. Royani b,3 \\ a Biology Education Study Program, PGRI Banjarmasin School of Teacher Training and Education (STKIP PGRI Banjarmasin) \\ Jl. Sultan Adam Kompleks H. Iyus No 18 Banjarmasin, Kalimantan Selatan, 70121, Indonesia \\ ${ }^{b}$ Mathematic Education Study Program, PGRI Banjarmasin School of Teacher Training and Education (STKIP PGRI Banjarmasin) \\ J. Sultan Adam Kompleks H. Iyus No 18 Banjarmasin, Kalimantan Selatan, 70121 \\ ${ }^{1}$ abidinsyah@stkipbjm.ac.id; ${ }^{2}$ sitiramdiah@stkipbjm.ac.id*; ${ }^{3}$ hmroyani@stkipbjm.ac.id \\ ${ }^{*}$ Corresponding author
}

\begin{tabular}{|c|c|}
\hline ARTICLE INFO & ABSTRACT \\
\hline $\begin{array}{l}\text { Article history } \\
\text { Received September 26, } 2019 \\
\text { Revised October 30, 2019 } \\
\text { Accepted November 23, } 2019 \\
\text { Published November 30, } 2019 \\
\text { Keywords } \\
\text { 21st-century learning } \\
\text { HOTS } \\
\text { local wisdom-based learning }\end{array}$ & $\begin{array}{l}\text { The use of local wisdom as learning sources and the empowerment of students' Higher- } \\
\text { Order Thinking Skills (HOTS) are the two components that must be carried out in the } \\
21 \text { st-century biology learning. The purpose of this study was to explore the information } \\
\text { about the application of local wisdom-based learning and HOTS-based assessment in } \\
\text { Banjarmasin. This survey research involved } 41 \text { high school biology teachers in } \\
\text { Banjarmasin who joined in Biology Teacher Working Group activities as research } \\
\text { samples. The research instruments were questionnaires that were validated by experts. } \\
\text { The data were analyzed using descriptive statistics in term of percentage. The findings } \\
\text { showed that the teacher gave a positive response to the content of local wisdom to be a } \\
\text { source of biology learning. In addition, they believed that through the learning, the } \\
\text { students caring attitudes towards the potential and local wisdom of South Kalimantan } \\
\text { were developed. Nonetheless, the empowerment of HOTS was not optimal as it was } \\
\text { less frequent for the teachers to design HOTS-based learning in their class. } \\
\text { This is an open access article under the CC-BY-SA license } \\
\text { C. }\end{array}$ \\
\hline
\end{tabular}

\section{INTRODUCTION}

In this era, local wisdom-based learning ( $L b L)$ is starting to be seen as a potential innovative learning. Through the application of LbL, students' knowledge and understanding can be improved (Hairida, 2017; Uge, Neolaka, \& Yasin, 2019), as well as learning outcomes (Ningrum, Nandi, \& Sungkawa, 2018). LbL was also reportedly able to empower students' critical thinking (Oktavia, Usmeldi, \& Yohandri, 2018; Putri \& Aznam, 2019). In line with these findings, students' problem-solving skills can also be improved (Kristanto, Suharno, \& Gunarhadi, 2019; Putri \& Aznam, 2019). Not surprisingly, LbL is considered a suitable learning implemented in the 21st Century (Jumriani \& Prasetyo, 2017). 
LbL is also considered very appropriate to be used in Indonesia where this country is known for its diversity of ethnicities, languages and traditions (Albantani \& Madkur, 2018; Arifin, Ananta, Utami, Handayani, \& Pramono, 2015; Asfina \& Ovilia, 2017). By utilizing local wisdom, students' conservation character can be developed (Khusniati, Parmin, \& Sudarmin, 2017). The application of LBL also fosters other positive characters (Subali, Sopyan, \& Ellianawati, 2015). In line with those research results, various local wisdom-based learning source and learning media were developed in various countries, especially in Indonesia. (Anwari, Nahdi, \& Sulistyowati, 2016; Oktavia et al., 2018; Tanjung, Daulay, \& Ghafari, 2018; Uge et al., 2019; Yoda, 2017).

From the point of view of the learning process, $\mathrm{LbL}$ can optimize student understanding of the concepts being studied. The reason is, by using $\mathrm{LbL}$, the teacher will associate the concepts learned by students with real-world phenomena. The ability of teachers to bring real phenomena from the surrounding environment to the learning process will increase the meaningfulness of learning (Agra et al., 2019; Huang, Chiu, Liu, \& Chen, 2011; Symeonidis \& Schwarz, 2016). Learning that able to direct students to learn their surrounding environment is also reported could to increase students' concentration and interest (Sulaiman, Azlan, \& Anis, 2011). In addition, this kind of condition will also increase student motivation (Danis, Perangin-Angin, \& Milfayetty, 2017; Kuhn \& Müller, 2014). Therefore, even though text books in Indonesia are not LbL-oriented (Jufrida, Basuki, Xena, \& Pasminingsih, 2019), LbL-oriented learning design is still highly recommended.

In line with LbL, learning oriented towards higher-order thinking skills (HOTS) is also seen as urgent to be implemented in the current era. HOTS empowerment is considered important because it has an essential role in forming graduates who are ready to face the 21st Century's challenges (Chalkiadaki, 2018; Pratama \& Retnawati, 2018). The characteristics of science learning are actually very appropriate in the empowerment students' HOTS (Daud, Omar, Turiman, \& Osman, 2012; Evagorou \& Dillon, 2009; Forawi, 2016). The reason, science education focuses on logical, argumentative, and systematic understanding of several phenomena. Science learning also requires students to think critically, creatively, and skillfully at solving problems. HOTS empowerment is also considered essential because students are trained to make the best decisions to think critically in analyzing arguments. In addition, mastering HOTS enables students to see concepts holistically and reflect effective thinkers' attitudes, be persistent with deep thinking, and be sensitive to the context of current issues (Shukla \& Dungsungnoen, 2016).

In designing HOTS-based learning, teachers must be able to pay attention to various aspects of learning for the optimal learning process. Applying appropriate learning activities (Al-Mubaid, Abukmail, \& Bettayeb, 2016; Ramirez \& Ganaden, 2008) as well as designing appropriate learning evaluation processes (McNeill, Gosper, \& $\mathrm{Xu}, 2012$ ) will optimize efforts to empower thinking skills. HOTS-oriented learning will be useless if the teacher is not able to provide HOTS-based assessment. This condition will cause the teacher not able to measure the success of the learning process.

When discussing the urgency and its benefits, it appears that LbL and HOTS-based learning are evident, so the implementation of both learning must be conducted at this time. To optimize the achievement of these targets, various studies examining both are often conducted. Research and development that seeks to develop learning tools oriented to local wisdom is increasingly conducted (Anwari et al., 2016; Uge et al., 2019; Zukmadini, Jumiarni, \& Kasrina, 2018). On the other hand, research on HOTS also often examines the effect of various forms of learning on student HOTS improvement (Abrami et al., 2014; Asyari, Muhdhar, Susilo, \& Ibrahim, 2016; Ramdiah, Abidinsyah, \& Mayasari, 2018), designing HOTS assessments (Kurniawan \& Lestari, 2019), or profiling HOTS level (Abdullah, Albeta, \& Ardiansyah, 2018). From this description, it can be seen that research examining teacher responses to LbL and the frequency of using HOTS assessments is still difficult to find. In fact, the study of teacher responses is important to see the teacher's perspective on this kind of learning. This information can be used as a basis for optimizing LbL in schools. Likewise, data about the frequency of using HOTS-based assessments is also important because the evaluation process is one of the three basic components of each learning. Therefore, the purpose of this study was to survey teachers' responses to LbL and the frequency with which they applied the HOTS-based assessment.

\section{METHOD}

This survey research was using quantitative approach. The research focused on to provide information on the response of high school biology teachers about the implementation LbL and HOTS-based assessment. The population in this study was all high school biology teachers in Banjarmasin City. The research sample was 41 high school biology teachers in Banjarmasin who were involved in routine Biology Teacher Working Group activities.

The research instrument was in the form of questionnaires that has validated by experts. The questionnaire was then filled by high school biology teachers in Banjarmasin City. The collected data were in the form of 
information on the teacher's response to the local wisdom of South Kalimantan as a student learning source and assessment of student learning outcomes in biology learning at Banjarmasin high schools. Furthermore, the data were analyzed using descriptive statistics by percentages, which aimed to describe the obtained data from the results of questionnaires that had been filled by the high school biology teachers.

\section{RESULTS AND DISCUSSION}

Indonesia has a variety of local wisdom that still needs to be explored and preserved. Aside from being a nation's wealth, local wisdom can be used as a source of learning in various subjects. Therefore, LbL is a recommended learning applied in biology subjects. The frequency of application and the perception of teachers in Kalimantan towards $\mathrm{LbL}$ is presented in Table 1.

Table 1. Frequency of teacher responses to LbL implementation in Banjarmasin

\begin{tabular}{|c|c|}
\hline Aspects & Approval frequencies (\%) \\
\hline Have designed LbL based on local potential in Banjarmasin & 95.12 \\
\hline Informing the natural potential in Banjarmasin while studying biology & 95.12 \\
\hline Local wisdom in South Kalimantan is important as a source of learning biology & 100 \\
\hline Implementing LbL can increase student awareness of local wisdom in South Kalimantan & 97.56 \\
\hline
\end{tabular}

Based on the analysis results, it could be informed that the teachers gave a positive response to the LbL implementation in biology learning. The results also showed that teachers strongly believe that through information and learning resources based on local wisdom will develop students' caring attitude towards the environment and the nature in South Kalimantan. When examined more deeply, $L b L$ is urgent to be implemented in biology learning, especially LbL can support several concepts taught in biology. Some concepts that can be taught using LbL, such as the role of plants in the survival of the earth, environmental changes, biodiversity, ecosystems, fungi, bacteria, and biotechnology.

The survey results also show that the majority of teachers believe that implementing $\mathrm{LbL}$ can improve students' understanding of the local wisdom around them. Through LbL, students will get to know the local wisdom around them. These conditions will affect students' character development. In addition, by raising local wisdom, teachers can direct students to learn biological concepts through real phenomena that occur in nature. The significance of the learning process will increase and could improve students' understanding about what they are learning (Islakhiyah, Sutopo, \& Yulianti, 2018). This condition will also increase student motivation (Albrecht \& Karabenick, 2018). As has been reported in previous studies, motivation is an important predictor of learning success (Kappe \& Flier, 2012; Vero \& Puka, 2017).

In addition to the benefits that have been delivered, LbL also has the potential to empower various skills needed by students today. Several studies report, by involving local wisdom in learning, students' thinking skills can be empowered better (Putri \& Aznam, 2019; Wahyuni, 2015). The ability to solve which is an important competency in the current era can also be improved (Kristanto et al., 2019; Putri \& Aznam, 2019). Several other research reports also inform that LbL can increase student literacy (Jumriani \& Prasetyo, 2017; Setiawan, Innatesari, Sabtiawan, \& Sudarmin, 2017). Moreover, some previous reports also reported that LbL applicants can increase students' interest in local culture (Damayanti, Dewi, \& Akhlis, 2013). Other studies in several different location were also report the same findings (Mannan, Sopyan, \& Sunarno, 2015; Yusa \& Jayanegara, 2014). Thus, by paying attention to local wisdom, the learning process can accommodate the needs of the $21^{\text {st }}$ century.

Unfortunately, the results of the survey using the HOTS-based assessment (Table 2) did not get results in line with $\mathrm{LbL}$. Based on Table 2, the general tendency that can be obtained is the higher the cognitive level, the lower the frequency of teachers who state that they often develop. Assessments that evaluate cognitive levels of $\mathrm{C} 1$ (remember) and C2 (understand) were the assessments most often developed by teachers in South Kalimantan. Noted, nearly $80 \%$ of teachers often develop assessments that evaluate student understanding. On the other hand, more than $30 \%$ of teachers have never developed an assessment that evaluates the ability to create (C6). This finding indicates that teachers have not yet positioned HOTS empowerment as an important part of learning.

In fact, learning that could empower HOTS is learning needed in the 21st Century (Darling-hammond, 2014; Ennis, 2011; Heong et al., 2011; Magsino, 2014; Trilling \& Fadel, 2009). The teacher has a very important role in determining the quantity and quality of teaching that is carried out (Bennett, Agostinho, \& Lockyer, 2016; Ferguson-Patrick, 2018; Hyslop-Margison \& Sears, 2010; Looney, Cumming, Kleij, \& Harris, 2017; Mahini, Forushan, \& Haghani, 2012). Therefore, teachers must think and plan carefully in increasing learning opportunities for students and improving the quality of teaching and reflecting on it (Benade, 2015; Lamb, 
2017). Unfortunately, during this time biology teachers have implemented learning programs are good but not maximized in applying HOTS (Ramdiah, Abidinsyah, Royani, \& Husamah, 2019).

Table 2. Frequency distribution of assessment implementation at various cognitive levels by teachers in Banjarmasin

\begin{tabular}{lcccc}
\hline \multirow{2}{*}{ Aspects accessed } & \multicolumn{4}{c}{ Implementation frequencies (\%) } \\
\cline { 2 - 5 } & Very often & Often & Seldom & Never \\
\hline Remembering & 24.39 & 65.85 & 7.32 & 2.44 \\
Understanding & 7.32 & 78.04 & 12.2 & 2.44 \\
Applying & 4.88 & 39.02 & 53.65 & 2.44 \\
Analyzing & 4.88 & 41.46 & 53.66 & 0 \\
Evaluating & 4.88 & 39.02 & 43.9 & 12.2 \\
Creating & 0 & 7.32 & 60.98 & 31.7 \\
Deducing & 0 & 21.95 & 60.98 & 17.07 \\
Reducing & 0 & 17.07 & 63.41 & 19.51 \\
Deciding and implementing & 4.88 & 21.95 & 58.54 & 14.63 \\
\hline
\end{tabular}

The urgency of designing learning activities and evaluating learning oriented to the empowerment of HOTS should be immediately recognized by teachers in South Kalimantan. Not surprisingly, educational research in various countries has long focused on learning optimization that is able to empower students' HOTS. In Israel, learning that implements innovative strategies and embedded thinking tools is reported to be able to empower the thinking skills of elementary and middle school students (Vidergor, 2018). In Canada, teachers from kindergarten through grade 9 believe that HOTS is needed by their students (Schulz \& Fitzpatrick, 2016). In fact, in Malaysia, STEM is recommended to be implemented to improve critical and creative thinking skills, problem solving, and scientific thinking of students (Baharin, Kamarudin, Abdul, \& Manaf, 2018). In line with this, in Malaysia, the application of authentic assessments is reported to have the potential to measure students' HOTS (Mohamed \& Lebar, 2017). Therefore, Indonesia must also take these steps so as not to compete with these countries more and more.

Based on the discussions that have been conveyed, it can be seen that in South Kalimantan most of the teachers have implemented LbL. Unfortunately, they are still not optimal in implementing HOTS-based assessment. The two conditions of learning are urgent in the 21st Century, both for the demands of the times and to increase the effectiveness of learning. The two conditions of learning can actually be made into a series of interrelated learning activities. The teacher can apply LbL during the learning process and when the evaluation phase the teacher uses HOTS-based assessments. Through analyzing local wisdom around them, students are directed to improve their HOTS. Therefore, the assessment used by the teacher should be in line with these learning activities.

\section{CONCLUSION}

Based on the findings of this study, it can be concluded that the teachers gave a positive response to the effort to design and implement the LbL. They are also aware of the importance and benefits of applying LbL in learning biology. Unfortunately, unlike $\mathrm{LbL}$, teachers are still not optimally using assessments oriented to HOTS. They are more likely to evaluate at a low cognitive level. In response, teachers are expected to be more aware and more motivated to empower HOTS students more. HOTS-oriented evaluation preparation training also needs to be carried out by related agencies. Research that seeks to develop learning that links LbL with HOTS-based assessment also needs to be done. The hope, with such research, will initiate the emergence of a variety of innovative learning that accommodates both of it.

\section{ACKNOWLEDGMENT}

This research was funded by the Ministry of Research, Technology, and Higher Education, Republic of Indonesia through the second year Competency Based Research Grant Scheme with contract number: 657/L11/KM/2019. We would like to express our deepest gratitude to the ministries, LLDIKTI Region XI, and our institutions so that this research can be carried out well.

\section{REFERENCES}

Abdullah, A., Albeta, S. W., \& Ardiansyah, A. (2018). Profile of chemical teacher candidates' higher order 
thinking skills (HOTS) on ionic equilibrium in solution topic. Unnes Science Education Journal, 7(3), 300-305. doi: https://doi.org/10.15294/usej.v7i3.23064

Abrami, P. C., Bernard, R. M., Borokhovski, E., Waddington, D. I., Wade, C. A., \& Persson, T. (2014). Strategies for teaching students to think critically: A meta-analysis. Review of Educational Research, 20(10), 1-40. doi: https://doi.org/10.3102/0034654314551063

Agra, G., Formiga, N. S., Oliveira, P. S. de, Costa, M. M. L., Fernandes, M. das G. M., \& Nóbrega, M. M. L. da. (2019). Analysis of the concept of meaningful learning in light of the Ausubel's Theory. Revista Brasileira de Enfermagem, 72(1), 248-255. doi: https://doi.org/10.1590/0034-7167-2017-0691

Al-Mubaid, H., Abukmail, A., \& Bettayeb, S. (2016). Empowering deep thinking to support criticaly thinking in teaching and learning. In Proceedings of the 2016 ACM SIGMIS Conference on Computers and People Research - SIGMIS-CPR '16 (pp. 69-75). doi: https://doi.org/10.1145/2890602.2890606

Albantani, A. M., \& Madkur, A. (2018). Think globally, act locally: The strategy of incorporating local wisdom in foreign language teaching in Indonesia. International Journal of Applied Linguistics and English Literature, 7(2), 1-8. doi: https://doi.org/10.7575/aiac.ijalel.v.7n.2p.1

Albrecht, J. R., \& Karabenick, S. A. (2018). Relevance for learning and motivation in education. The Journal of Experimental Education, 86(1), 1-10. doi: https://doi.org/10.1080/00220973.2017.1380593

Anwari, A., Nahdi, M. S., \& Sulistyowati, E. (2016). Biological science learning model based on Turgo's local wisdom on managing biodiversity. In AIP Conference Proceedings (Vol. 1708, p. 030001). doi: https:/l doi.org/10.1063/1.4941146

Arifin, E. N., Ananta, A., Utami, D. R. W. W., Handayani, N. B., \& Pramono, A. (2015). Quantifying Indonesia's ethnic diversity. Asian Population Studies, 11(3), 233-256. doi: https://doi.org/10.1080/17441730.2015. 1090692

Asfina, R., \& Ovilia, R. (2017). Be proud of Indonesian cultural heritage richness and be alert of its preservation efforts in the global world. Humanus, 15(2), 195-206. doi: https://doi.org/10.24036/jh.v15i2. 6428

Asyari, M., Muhdhar, M. H. I. A., Susilo, H., \& Ibrahim, I. (2016). Improving critical thinking skills thorugh the intergration of problem based learning and grup investigation. International Journal for Lesson and Learning Studies, 5(1), 36-44. Retrieved from http://cyber.sci-hub.tw/MTAuMTEwOc9pamxscy0Xmc OyMDEOLTAwNDI=/10.1108\%40IJLLS-10-2014-0042.pdf

Baharin, N., Kamarudin, N., Abdul, U. K., \& Manaf, A. (2018). Integrating STEM education approach in enhancing higher order thinking skills. International Journal of Academic Research in Business and Social Sciences, 8(7), 810-821. doi: https://doi.org/10.6007//JARBSS/v8-i7/4421

Benade, L. (2015). Teachers' critical reflective practice in the context of twenty-first century learning. Open Review of Educational Research, 2(1), 42-54. doi: https://doi.org/10.1080/23265507.2014.998159

Bennett, S., Agostinho, S., \& Lockyer, L. (2016). The process of designing for learning: understanding university teachers design work. Educational Technology Research and Development, 65(1), 1-21. doi: https://doi.org/10.1007/s11423-016-9469-y

Chalkiadaki, A. (2018). A systematic literature review of 21st century skills and competencies in primary education. International Journal of Instruction, 11(3), 1-16. doi: https://doi.org/10.12973/iji.2018.1131a

Damayanti, C., Dewi, N. R., \& Akhlis, I. (2013). Pengembangan CD pembelajaran berbasis kearifan lokal tema getaran dan gelombang untuk siswa SMP kelas VIII. USEJ - Unnes Science Education Journal, 2(2), 274-281. doi: https://doi.org/10.15294/usej.v2i2.2036

Danis, A., Perangin-Angin, R. B. B., \& Milfayetty, S. (2017). The effect of contextual teaching and learning (CTL) and motivation to students ' achievement in learning civics in grade VII SMP Imelda Medan. IOSR Journal of Research \& Method in Education (IOSR-JRME), 7(6), 24-33. doi: https://doi.org/10.9790/738 8-0706012433

Darling-hammond, L. (2014). Constructing 21st-century teacher education. Journal of Teacher Education, 57(3), 300-314. doi: https://doi.org/10.1177/0022487105285962

Daud, A. M., Omar, J., Turiman, P., \& Osman, K. (2012). Creativity in science education. In Procedia - Social and Behavioral Sciences (Vol. 59, pp. 467-474). doi: https://doi.org/10.1016/j.sbspro.2012.09.302

Ennis, R. H. (2011). The nature of critical thinking: An outline of critical thinking dispositions and abilities. Retrieved from http://faculty.education.illinois.edu/rhennis/ documents/TheNatureofCriticalThinking_517 11_000.pdf

Evagorou, M., \& Dillon, J. (2009). Infusing thinking skills in the science classroom: System thinking and argumentation as a means to engage students in the process reasoning. In M. Saleh \& M. S. Khine 
(Eds.), Fostering Scientific Habits of Mind. Brill | Sense. doi: https://doi.org/10.1163/9789087909239 007

Ferguson-Patrick, K. (2018). The importance of teacher role in cooperative learning: the effects of high-stakes testing on pedagogical approaches of early career teachers in primary schools. Education 3-13, 46(1), 89-101. doi: https://doi.org/10.1080/03004279.2016.1189946

Forawi, S. A. (2016). Standard-based science education and critical thinking. Thinking Skills and Creativity, 20, 52-62. doi: https://doi.org/10.1016/j.tsc.2016.02.005

Hairida, H. (2017). Using learning Science, Environment, Technology and Society (SETS) local wisdom and based colloids teaching material. JETL (Journal Of Education, Teaching and Learning), 2(1), 84-89. doi: https://doi.org/10.26737/jetl.v2i1.146

Heong, Y. M., Othman, W. B., Yunos, J. Bin, Kiong, T. T., Hassan, R. Bin, Mohaffyza, M., \& Mohamad, B. (2011). The level of Marzano higher order thinking skills among tTechnical education students. International Journal of Social Science and Humanity, 1(2), 121-125. Retrieved from http://ijssh.org/ papers/20-H009.pdf

Huang, Y.-M., Chiu, P.-S., Liu, T.-C., \& Chen, T.-S. (2011). The design and implementation of a meaningful learning-based evaluation method for ubiquitous learning. Computers \& Education, 57(4), 2291-2302. doi: https://doi.org/10.1016/j.compedu.2011.05.023

Hyslop-Margison, E. J., \& Sears, A. M. (2010). Enhancing teacher performance: The role of professional autonomy. Interchange, 41(1), 1-15. doi: https://doi.org/10.1007/s10780-010-9106-3

Islakhiyah, K., Sutopo, S., \& Yulianti, L. (2018). Scientific explanation of light through phenomenon-based learning on junior high school student. In Proceedings of the 1st Annual International Conference on Mathematics, Science, and Education (ICoMSE 2017). Paris, France: Atlantis Press. doi: https://doi. org/10.2991/icomse-17.2018.31

Jufrida, J., Basuki, F. R., Xena, A., \& Pasminingsih, P. (2019). Gap analysis and the potential of local wisdom Jambi as science learning resources. Jurnal Penelitian \& Pengembangan Pendidikan Fisika, 5(2), $77-$ 82. doi: https://doi.org/10.21009/1.05202

Jumriani, J., \& Prasetyo, Z. K. (2017). Important roles of local potency based science learning to support the 21st century learning. European Journal of Engineering and Formal Sciences, 1(1), 6-16. doi: https:/l doi.org/10.26417/ejef.v1i1.p6-16

Kappe, R., \& Flier, H. Van Der. (2012). Predicting academic success in higher education: What's more important than being smart? European Journal of Psychology of Education, 27(4), 605-619. doi: https:/l doi.org/10.1007/s10212-011-0099-9

Khusniati, M., Parmin, P., \& Sudarmin, S. (2017). Local wisdom-based science learning model through reconstruction of indigenous science to improve student's conservationist character. Journal of Turkish Science Education, 14(3), 16-23. doi: https://doi.org/10.12973/tused.10202a

Kristanto, A., Suharno, S., \& Gunarhadi, G. (2019). Promoting local wisdom in international primary curriculum aims to develop learners' problem solving skills. International Journal of Educational Research Review, 4(3), 439-447. doi: https://doi.org/10.24331/ijere.573947

Kuhn, J., \& Müller, A. (2014). Context-based science education by newspaper story problems: A study on motivation and learning effects. Perspectives in Science, 2(1-4), 5-21. doi: https://doi.org/10.1016/j. pisc.2014.06.001

Kurniawan, R. Y., \& Lestari, D. (2019). The development assessment instruments of higher order thinking skills on economic subject. Dinamika Pendidikan, 14(1), 102-115. doi: https://doi.org/10.15294/dp.v1 $4 i 1.19226$

Lamb, J. (2017). How do teachers reflect on their practice? A study into how feedback influences teachers' reflective practice. The STeP Journal, 4(4), 94-104. Retrieved from https://ojs.cumbria.ac.uk/index.php/ step/article/download/427/549

Looney, A., Cumming, J., Kleij, F. van Der, \& Harris, K. (2017). Reconceptualising the role of teachers as assessors: teacher assessment identity. Assessment in Education: Principles, Policy and Practice, (January), 1-26. doi: https://doi.org/10.1080/0969594X.2016.1268090

Magsino, R. M. (2014). Enhancing higher order thinking skills in a marine biology class through ProblemBased Learning. Asia Pacific Journal of Multidisciplinary Research, 2(5), 1-6. Retrieved from http://www.apjmr.com/wp-content/uploads/2014/09/APJMR-2014-2-116.pdf

Mahini, F., Forushan, Z. J.-A., \& Haghani, F. (2012). The Importance of teacher's role in technology-based education. Procedia - Social and Behavioral Sciences (Vol. 46, pp. 1614-1618). doi: https://doi.org/10. 


\section{6/j.sbspro.2012.05.348}

Mannan, M. N., Sopyan, A., \& Sunarno, S. (2015). Pengembangan perangkat pembelajaran berbasis kearifan lokal untuk mengembangkan karakter positif siswa SD. Jurnal Inovasi Dan Pembelajaran Fisika, 2(2), 141-146. doi: https://doi.org/10.36706/jipf.v2i2.2615

McNeill, M., Gosper, M., \& Xu, J. (2012). Assessment choices to target higher order learning outcomes: The power of academic empowerment. Research in Learning Technology, 20(3), 283-296. doi: https://doi. org/10.3402/rlt.v20i0.17595

Mohamed, R., \& Lebar, O. (2017). Authentic assessment in assessing higher order thinking skills. International Journal of Academic Research in Business and Social Sciences, 7(2), 466-476. doi: https://doi.org/10.6007/IJARBSS/v7-i2/2021

Ningrum, E., Nandi, N., \& Sungkawa, D. (2018). The impact of local wisdom-based learning model on students' understanding on The land ethic. In IOP Conference Series: Earth and Environmental Science (Vol. 145, p. 012086). doi: https://doi.org/10.1088/1755-1315/145/1/012086

Oktavia, R. A., Usmeldi, U., \& Yohandri, Y. (2018). Development of physics learning material based on problem based learning by integrating local wisdom West Sumatra to improve critical thinking ability of students. International Journal of Progressive Sciences and Technologies (IJPSAT), 553(2), 544-553. Retrieved from http://ijpsat.ijsht-journals.org/index.php/ijpsat/article/download/258/164

Pratama, G. S., \& Retnawati, H. (2018). Urgency of Higher Order Thinking Skills (HOTS) content analysis in mathematics textbook. In Journal of Physics: Conference Series (Vol. 1097). doi: https://doi.org/10. 1088/1742-6596/1097/1/012147

Putri, A. S., \& Aznam, N. (2019). The effect of the science web module integrated on batik's local potential towards students' critical thinking and problem solving (thinking skill). Journal of Science Learning, 2(3), 92-96. doi: https://doi.org/10.17509/jsl.v2i3.16843

Ramdiah, S., Abidinsyah, A., Royani, M., \& Husamah, H. (2019). Understanding, planning, and implementation of HOTS by senior high school biology teachers in Banjarmasin-Indonesia. International Journal of Instruction, 12(1). Retrieved from http://www.e-iji.net/dosyalarliji_2019_1_28.pdf

Ramdiah, S., Abidinsyah, H., \& Mayasari, R. (2018). Problem-based learning: Generates higher-order thinking skills of tenth graders in ecosystem concept. JPBI (Jurnal Pendidikan Biologi Indonesia), 4(1), 29. doi: https://doi.org/10.22219/jpbi.v4i1.5490

Ramirez, R. P. B., \& Ganaden, M. S. (2008). Creative activities and students' higher order thinking skills. Education Quarterly, 66(1), 22-33. Retrieved from http://citeseerx.ist.psu.edu/viewdoc/download? doi $=10 \cdot 1 \cdot 1 \cdot 824.9279 \&$ rep $=$ rep $1 \&$ type $=p d f$

Schulz, H., \& Fitzpatrick, B. (2016). Teachers' understandings of critical and higher order thinking and what this means for their teaching and assessments. Alberta Journal of Educational Research, 62(1), 61-86. Retrieved from https://journalhosting.ucalgary.ca/index.php/ajer/article/download/56168/pdf

Setiawan, B., Innatesari, D. K., Sabtiawan, W. B., \& Sudarmin, S. (2017). The development of local wisdombased natural science module to improve science literation of students. Jurnal Pendidikan IPA Indonesia, 6(1), 49-54. doi: https://doi.org/10.15294/jpii.v6i1.9595

Shukla, D., \& Dungsungnoen, A. P. (2016). Student's perceived level and teachers' teaching strategies of higher order thinking skills; A study on higher educational institutions in Thailand. Journal of Education and Practice, 7(12), 211-219. Retrieved from https://files.eric.ed.gov/fulltext/EJ1099486.pdf

Subali, B., Sopyan, A., \& Ellianawati, E. (2015). Developing local wisdom based science learning design to establish positive character in elementary school. Jurnal Pendidikan Fisika Indonesia, 11(1), 1-7. doi: https://doi.org/10.15294/jpfi.v11i1.3998

Sulaiman, W. I. W., Azlan, M. H. M., \& Anis, A. (2011). Learning outside the classroom: Effects on student concentration and interest. In Procedia - Social and Behavioral Sciences (Vol. 18, pp. 12-17). doi: https://doi.org/10.1016/j.sbspro.2011.05.003

Symeonidis, V., \& Schwarz, J. F. (2016). Phenomenon-based teaching and learning through the pedagogical lenses of phenomenology: The recent curriculum reform in Finland. Forum Oświatowe, 28(2), 31-47. Retrieved from http://forumoswiatowe.pl/ index.php/czasopismo/article/view/458

Tanjung, P., Daulay, S., \& Ghafari, O. F. (2018). The development of local wisdom of Labuhanbatu based on teaching material of descriptive text for 7th Grade student at SMP Negeri 1 Bilah Barat, Indonesia. International Journal of Education, Learning and Development, 6(1), 80-92. Retrieved from http://www.eajournals.org/wp-content/uploads/The-Development-of-Local-Wisdom-of-Labuhanbatu-Bas ed-on-Teaching-Material-of-Descriptive-Text-For-7th-Grade-Student-at-Smp-Negeri-1-Bilah-Barat-Indo 
nesia.pdf

Trilling, B., \& Fadel, C. (2009). 21st century skills: Learning for life in our times. San Francisco: Jossey-Bass. Retrieved from https://psycnet.apa.org/record/2009-18745-000

Uge, S., Neolaka, A., \& Yasin, M. (2019). Development of social studies learning model based on local wisdom in improving students' knowledge and social attitude. International Journal of Instruction, 12(3), 375-388. doi: https://doi.org/10.29333/iji.2019.12323a

Vero, E., \& Puka, E. (2017). The importance of motivation in an educational environment. Formazione \& Insegnamento $X V, 15(1), 57-66$. Retrieved from http://ojs.pensamultimedia.itlindex.php/siref/article/ viewFile/2164/1973

Vidergor, H. E. (2018). Effectiveness of the multidimensional curriculum model in developing higher-order thinking skills in elementary and secondary students. The Curriculum Journal, 29(1), 95-115. doi: https://doi.org/10.1080/09585176.2017.1318771

Wahyuni, S. (2015). Developing science learning instruments based on local wisdom to improve student's critical thinking skills. Jurnal Pendidikan Fisika Indonesia, 11(2), 156-161. doi: https://doi.org/10.15294/ jpfi .v11i2.4228

Yoda, I. K. (2017). The development of cooperative learning model based on local wisdom of Bali for physical education, sport and health subject in junior high school. In IOP Conference Series: Materials Science and Engineering (Vol. 180, p. 012166). doi: https://doi.org/10.1088/1757-899X/180/1/012166

Yusa, I. M. M., \& Jayanegara, I. N. (2014). Pengembangan aplikasi penyampaian kearifan lokal melalui cerita rakyat Bali untuk anak sekolah dasar berbasis mobile. Jurnal S@Cies, 5(1), 24-32. doi: https://doi. org/10.31598/sacies.v5i1.62

Zukmadini, A. Y., Jumiarni, D., \& Kasrina, K. (2018). Developing antimicrobial medicinal plants pocketbook based on local wisdom of Muko-Muko and Serawai ethnics. JPBI (Jurnal Pendidikan Biologi Indonesia), 4(2), 95-104. doi: https://doi.org/10.22219/jpbi.v4i2.5436 